\title{
绿色施工理念在建筑施工管理中的应用解析
}

\author{
覃洁 \\ 广西建工集团第五建筑工程有限责任公司 \\ DOI:10.32629/btr.v1i6.1714
}

[摘 要] 在建筑行业迅猛发展下,城市基础设施不断趋于完善, 在促进经济发展的同时,也带来了不同程度上的资源损耗和环 境污染。在可持续发展战略提出后, 建筑行业首当其中, 在建筑施工管理中渗透绿色施工理念十分关键, 选择节能环保型材料, 在满足建筑工程施工质量和安全需要的同时,尽可能降低能耗和环境污染。本文就建筑施工管理中绿色施工理念应用进行探 究,创新实施路径, 对于建筑企业市场竞争和发展具有积极作用。

[关键词] 绿色施工; 节能环保; 施工管理; 应用

在城市现代化建设进程不断加快下, 建筑行业规模不断扩 大, 大量高层建筑、超高层建筑涌现, 导致大量资源和能源损耗, 环境污染问题愈加严重。建筑工程施工中, 产生的废气、废水 和建筑垃圾都将对自然环境产生污染。建筑行业的污染问题已 经成为制约人类社会可持续发展的主要问题之一, 尽管我国颁 布了一系列绿色施工制度和政策, 但是建筑工程中的资源损耗 和环境污染问题仍然存在。故此, 应该将绿色施工理念全面贯 穿于建筑施工管理中应用, 提出合理措施来降低资源损耗和环 境污染, 打造环境友好型建筑。

\section{1 绿色施工理念概述}

绿色施工理念强调打造环境友好型建筑, 在相应工程周 期内, 实现资源和能源的合理配置, 在满足建筑工程施工需要 的同时, 尽可能降低资源损耗和环境污染, 维护生态平衡。在 可持续发展背景下, 打造环境友好型建筑, 就需要将绿色环保 理念贯穿于工程设计、施工全过程, 提升资源利用效率同时, 降低能耗和环境污染。绿色建筑施工中需要在绿色设计理念 支持下, 遵循节能降耗原则, 进一步加强建筑施工管理。绿色 建筑施工中, 需要建筑施工队伍具备较高专业能力和节能意 识, 应用绿色环保型材料和环保技术, 才能推动绿色建筑施工 活动有序开展。在当前时代背景下, 节能降耗是主要内容, 但 是在建筑工程施工中不可避免的产生建筑垃圾, 污染生态环 境。故此, 在绿色施工理念指导下, 推行全过程绿色施工管理, 选择科学合理的管理手段, 提升资源利用效率, 降低环境污染, 推动建筑行业可持续发展。

\section{2 建筑工程施工管理中的环保问题}

2.1 资源浪费现象严重

纵观建筑行业发展现状来看, 能源和资源消耗量较大, 对 于生态环境带来了不同程度上的污染。结合中国数据网统计 数据, 2016 年我国建筑业煤消费总量达到了 7991 万 $\mathrm{t}$, 电力消 费量为 725.6 亿 kWh。建筑工程施工中, 由于施工管理模式过 于粗放, 施工钢材料、机械设备和人员未能合理配置, 各个工 序之间衔接不畅, 加之信息传输和共享水平不足, 在一定程度 上加剧资源损耗, 延误工期。传统建筑工程施工中, 原材料运 输到施工现场加工处理, 可能由于人员自身意识不高, 影响到
施工效率和施工质量, 带来严重的资源损耗。此外, 部分建筑 单位为了缩短工期, 盲目追求面子工程, 设施和资源回收处理 不当, 带来严重的浪费资源。

\section{2 环保意识薄弱}

节能环保是现代社会发展的主旋律, 在建筑工程施工中需 要运用到大量的材料和设备, 但是由于资源的不合理配置, 导 致资源损耗严重, 未经处理直接排放到自然环境中, 为环境带 来严重的污染。究其根本, 是由于相关人员的环保意识薄弱, 无论是施工人员还是居民群众都缺少良好的环境保护习惯, 在 具体施工中将建筑垃圾、废水直接排放到周边区域, 污染周围 土壤、地下水与河流, 产生了严重的环境污染。建筑中产生的 固体废弃物回收利用度不高, 甚至部分企业为了降低处理成本, 偷偷掩埋在地下, 污染周边生态环境。

\section{3 施工技术陈旧、单一}

对于部分中小型的建筑施工队伍而言, 多数施工人员是 农民工组成, 此类人员并未接受过专门的教育和培训, 文化 素质和施工能力不足, 并未进行岗前培训, 直接上岗可能导 致工序混乱, 对于施工技术的掌握不充分, 即便是先进技术 和设备, 由于操作不姻熟, 影响到施工技术和设备原有作用 发挥, 影响到施工质量和安全。同时, 部分管理人员自身的环 保意识不足, 主要是以家族式用人方式为主, 管理人员缺乏 专业知识和能力, 自然无法将绿色施工理念贯穿于施工全过 程。即便部分国内大型的建筑企业已经将先进施工技术和设 备应用其中, 但在市场上的建筑企业中占比较少, 多数中小 型企业仍然采用传统施工技术和施工方式, 如锤击装会产生 大量噪音, 电焊切割钢材时产生的噪音会对周边居民生活带 来不良影响。

\section{4 绿色施工监管缺失}

建筑工程施工中, 绿色施工理念的应用需要配套监管体 制支持, 但是多数建筑工程施工中缺乏完善的绿色施工监管 体制, 施工理念陈旧。部分施工企业为了降低施工成本, 忽略 绿色施工理念的重要性, 追求利益最大化。这样施工完成后, 尽管工期大大缩短, 但是工程仍然会造成大量资源损耗, 对 生态环境带来污染, 不利于建筑企业的市场竞争和发展。 
3 建筑工程施工管理中绿色施工理念应用途径

3. 1 引进先进的施工技术, 降低施工能耗

在建筑工程施工中, 为了打造环境友好型建筑, 降低能源 损耗, 应该结合建筑工程施工情况, 引进先进的施工技术和设 备, 最大程度上降低施工能耗。以往建筑工程施工中, 机械设 备和建筑材料利用效率不高, 但是由于工艺陈旧严重影响到 施工活动有序开展。这就需要施工活动开始前, 对施工区域深 入勘察, 保证施工安全和施工进度前提下, 最大程度上降低能 耗和环境污染。

故此, 施工人员应该结合实际情况选择合理的设备和工 艺, 施工前对机械设备全面检查, 定期维护和保养, 确保机械 设备高效运行, 最大程度上降低设备故障几率。项目负责人 在选择先进施工技术和工艺同时, 应加强施工现场管理, 按 需取用材料, 减少材料的浪费, 提升资源利用效率。对于施工 中剩下的材料循环利用, 及时清理施工中的建筑垃圾, 运输 到专门建筑垃圾处理厂, 维护生态平衡。

3.2 编制合理的资源利用计划, 降低施工成本支出

建筑工程施工中, 将绿色施工理念应用到施工管理中, 正 确看待建筑工程施工中需要运用的材料。水资源是建筑工程 施工活动开展的主要资源, 需要编制科学合理的使用计划, 确 保资源使用更具针对性。施工期间, 为了降低施工成本费用, 应该结合绿色可持续发展要求, 引进前沿的技术和水资源利 用系统, 实现水资源循环利用, 尽可能减少自来水依赖程度, 缓解水资源匮乏问题。

3.3 加强材料质量把关, 实现资源合理配置

建筑工程施工中需要运用大量的材料, 材料质量高低直 接关乎到建筑工程施工质量和安全。这就需要做好建材市场 调查, 对比分析选择质量高、价格低的材料; 材料运输到施工 现场, 进行严格的质量检验后方可投入使用, 如果是有毒、有 害, 对环境污染较大的建材则禁止使用; 现场材料合理分类存 放, 避免虫蛙、受潮和损坏, 避免材料浪费, 提升资源利用效 率。同时, 还要保证材料选购人员的专业能力和职业素养, 根
据工程需要选择最佳的材料, 避免徇私舞弊和谋求私利现象 出现, 保证材料性能符合工程建设需要。

3.4 加强绿色施工监督, 减少环境污染

为了保证建筑工程施工质量, 降低资源损耗和环境污染, 应该进一步加强绿色施工监督, 建立完善的监管机制和体系, 可以选择第三方监督机构负责, 实现建筑工程施工全过程的 监管和控制。一旦发现安全问题和材料损耗问题, 及时制止, 保证施工活动有序开展。与此同时, 对于施工过程中产生的有 毒有害物质, 噪音和强光污染, 需要在封闭环境和隔音环境下 处理, 并使用先进的污水处理工艺来降低环境污染。

\section{4 结束语}

综上所述, 现代建筑工程建设中, 打造节能环保型建筑成 为主流趋势, 这就需要在施工管理中应用绿色施工理念, 贯穿 于施工全过程, 并在全面监管下, 降低资源损耗和环境污染, 有效提升施工质量和安全。只有这样, 才能打造符合可持续发 展需要的建筑产品, 提升企业市场竞争优势, 推动建筑行业现 代化发展。

\section{[参考文献]}

[1]朱卫卫.绿色施工管理理念下建筑工程施工管理创 新探究[J].科技经济导刊,2018,26(31):61.

[2]宋亚辉.试论基于绿色施工管理理念下如何创新建筑 施工管理[J].绿色环保建材,2018,11(10):225-226.

[3]郑国毅.绿色建筑施工管理的理念及在建筑施工管理 中的应用 [J].科技与企业,2013,23(12):56.

[4]吴超.绿色建筑施工管理的理念及在建筑施工管理中 的应用[J].中华民居(下旬刊),2014,(03):443-444。

[5]蔡新生.绿色施工管理理念在创新建筑施工管理模式 中的应用[J].住宅与房地产,2018,22(18):151。

[6]李文慧,李贺,高盼盼.浅析绿色施工管理理念在建筑 工程施工中的应用[J].建材与装饰,2018,34(05):197.

[7]应小青,杨华杰.绿色施工管理理念在创新建筑施工 管理模式中的应用 [J].科技与创新,2016,29(03):45. 